\title{
Effect of Consumption Ethic And Demography haracteristic on Prosperity in Islamic Economic Perspective (Case Study in Community of Tabagsel)
}

\author{
Rahmat Ilyas ${ }^{1}$, Amiur Nuruddin ${ }^{2}$, Muhammad Yusuf ${ }^{3}$ \\ ${ }^{I}$ PhD Student in Syariah Economic Program, Islamic State University of North Sumatera, Indonesia \\ ${ }^{2}$ Lecturer in Syariah Economic Program, Islamic State University of North Sumatera, Indonesia \\ ${ }^{3}$ Lecturer in Faculty of Economic, Medan State University, Indonesia
}

\begin{abstract}
The problem of development country is its people's prosperity. The prosperity is to be an important part of one country. This paper present to observe the phenomenon of prosperity in community of Tabagsel, especially in city of Padangsidimpuan and regency of South Tapanuli. This research uses a qualitative method. A path analysis is applied to analysis the relationship between variable. Questioner method is applied in this research to collect the data. The research result shows that there is effect of consumption ethic, demography characteristic, religious, income and government policy on the prosperity with significant value calculation in this research is $0.00<0.05$. The effect level of consumption ethic, demography characteristic, religious, income and government policy on the prosperity is $34.2 \%$. Whereas the balance of $65.8 \%$ is affected by the other factor.
\end{abstract}

Keywords - Consumption ethic, demography characteristic, prosperity

\section{INTRODUCTION}

The problem of development country is its people's prosperity. The prosperity is to be an important part of one country. The objective of country developed is to prosperous its people. Some ways, rules, things, phenomenological or policy have been choice and done by a country for achieving the objective. The basic conditions that should be fulfilled to achieve people's prosperity are: 1) The economic growth continuity; 2) The development of strong economic sector; and 3) the development of inclusive and trust economic [1]. The community prosperity will be achieved if the economic growth is increased and working area is created to give an working opportunity to people with a suitable salary.The definition of prosperity based on Indonesian dictionary comes from prosperous, it means peaceful, quiet, rich and safe (there is no kind of threat) [2]. The prosperity means also that the life requirement (material and spiritual) can be achieved for people. In the other meaning of prosperity is also that the basic rightful can be achieved, especially in civil freedom [3]. Islamic gives a meaning of prosperity in terminology of falah. It means holistic prosperity and balance between material and spiritual dimension, individual-social and prosperity in the world and the beyond. The terminology of prosperity in Islamic is not only a maximum rich and consumption, but it is needed to balance between requirement of material and spiritual. It is not enough to just praying for fulfilling the requirement of spiritual, but it is needed to be a suitable individual characteristic and social with syariah and the syariah objective. If one of aspect (material or spiritual) is eliminate, thus it will threat the pure prosperity and it will appear a criminal action, despondency, dependency of alcoholic drinking, narcotic, mentality illness and the other risk [4].

\section{METHODOLOGY}

\subsection{Research Location and Time}

This research location is focused in the community of South Tapanuli, especially in the community of Padangsidimpuan city and Regency of South Tapanuli, Province of North Sumatera. This research is conducted on April to October 2016.

\subsection{Research Phenomenological}

The research method is qualitative method. Based on [5] that the qualitative method is a research method that it is based on the positivism philosophy, it is reality as a concrete thing, it can be observed using the five senses, it can be categorized following the kind, form, color and characteristic, no change, it can be measured and verified. 
The path analysis is used to analyze the correlation between variables. It is useful to descript and test the correlation model between variable of reason consequence. It is applied by using the correlation and regression, thus it can be obtain the end dependent variable. It should be in the direct or intervening variable [5].

\subsection{Data Collection}

A questioner form is used in the collection of data. It is writing form that it is to obtain information and respondent in the individual report or some things that can be known [6]. The questioner form is rating scale, it is a question that followed by columns that they show levels, for example agree to disagree. The questioner form is given directly to the respondent.

\subsection{Data Analysis}

There are some statistical techniques that can be used to analyze the data. The objective of data analysis is to obtain the relevant information that it is contented in the data and it can be used to solve a problem.

1. Classic Assumption Test

The classic assumption test is a test that it is used as a requirement of regression method applying. The assumption is assumption of normality, multi-co-linearity and autocorrelation.

2. Hypothesis Test

This research use double regression analysis. This analysis is used to test the correlation of some independent variables to the dependent variables. And then to test the effect of independent variables to the prosperity should be tested following: determination coefficient test (adjusted $R^{2}$ ), simultaneous test ( $F$ test) and significant test ( $T$ test). Figure 1 shows a research concept.

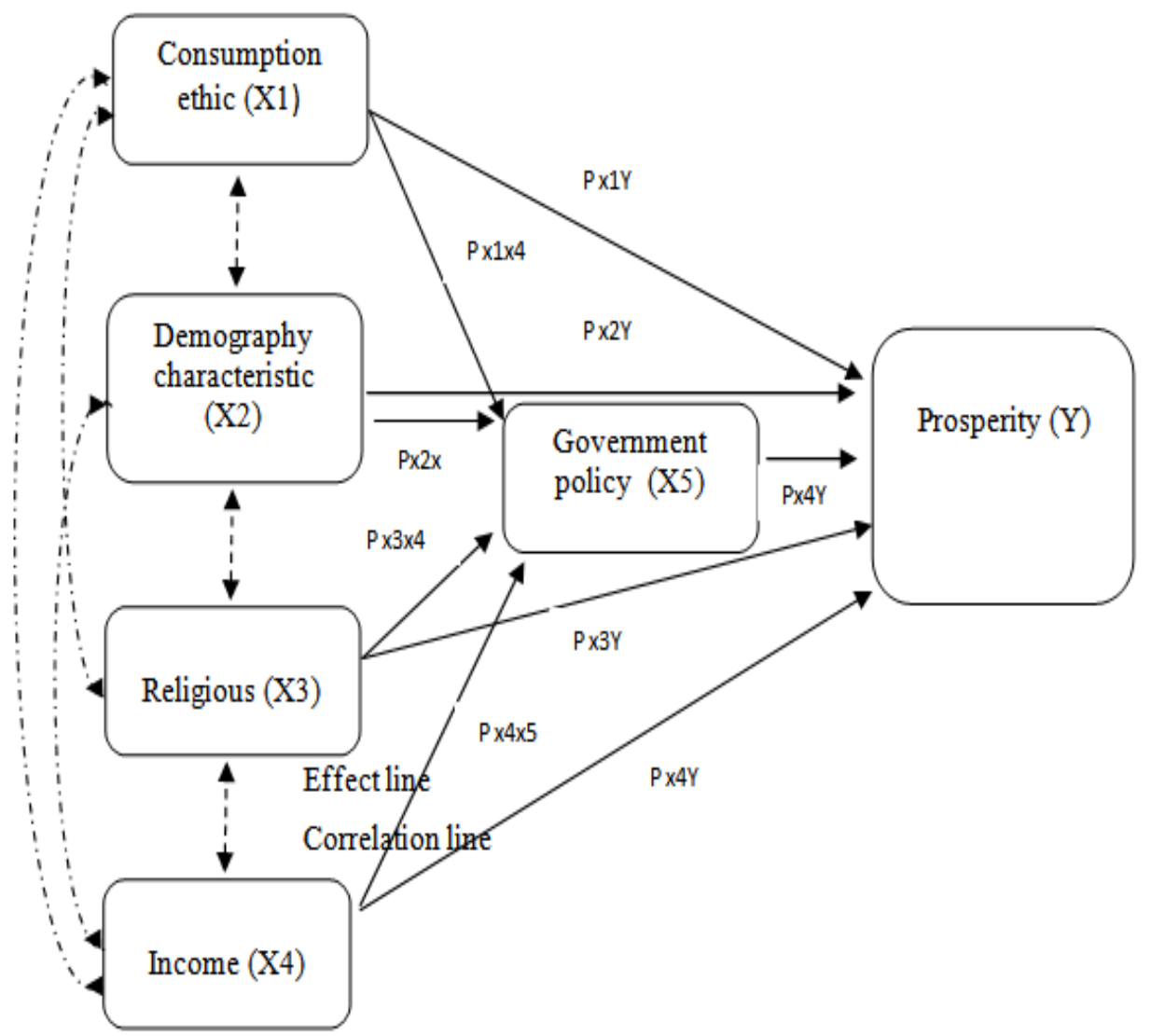

Figure 1. Frame of research concept

\subsection{Correlation Test Between Variable}

RESULT AND DISCUSSION

The correlation coefficient is a statistical tool that it can be used to compare the measurement result and the different variable to decide the correlation level between variable [6]. Based on the research conducted, thus the correlation between variable can be conclude as stated Table 1 below: 
Table 1. Correlation data analysis between variable

\begin{tabular}{|c|c|c|c|c|c|c|c|}
\hline & & $\begin{array}{l}\text { Consu } \\
\text { mption } \\
\text { ethic }\end{array}$ & $\begin{array}{l}\text { Demogra } \\
\text { phy } \\
\text { characte } \\
\text { ristic }\end{array}$ & $\begin{array}{c}\text { Religio } \\
\text { us }\end{array}$ & Income & $\begin{array}{l}\text { Governm } \\
\text { ent } \\
\text { policy }\end{array}$ & $\begin{array}{c}\text { Prospe } \\
\text { rity }\end{array}$ \\
\hline \multirow[t]{3}{*}{$\begin{array}{l}\text { Consumptio } \\
n \text { ethic }\end{array}$} & $\begin{array}{l}\text { Pearson } \\
\text { Correlation }\end{array}$ & 1 &, $551^{* *}$ & $446^{* *}$ & ,091 & $477^{* *}$ &, $408^{* *}$ \\
\hline & Sig. (2-tailed) & & ,000 &, 000 &, 069 & ,000 & ,000 \\
\hline & $\mathrm{N}$ & 398 & 398 & 398 & 398 & 398 & 398 \\
\hline \multirow{3}{*}{$\begin{array}{l}\text { Demography } \\
\text { characteristi } \\
\text { c }\end{array}$} & $\begin{array}{l}\text { Pearson } \\
\text { Correlation }\end{array}$ &, $551^{* *}$ & 1 & $453^{* *}$ & 087 & $495^{* *}$ & $405^{* *}$ \\
\hline & Sig. (2-tailed) &, 000 & & , 000 &, 084 &, 000 & ,000 \\
\hline & $\mathrm{N}$ & 398 & 398 & 398 & 398 & 398 & 398 \\
\hline \multirow[t]{3}{*}{ Religious } & $\begin{array}{l}\text { Pearson } \\
\text { Correlation }\end{array}$ & $446^{* *}$ & $453^{* *}$ & 1 & $165^{* *}$ &, $682^{* *}$ &, $478^{* *}$ \\
\hline & Sig. (2-tailed) &, 000 & ,000 & & ,001 & ,000 & ,000 \\
\hline & $\mathrm{N}$ & 398 & 398 & 398 & 398 & 398 & 398 \\
\hline \multirow[t]{3}{*}{ Income } & $\begin{array}{l}\text { Pearson } \\
\text { Correlation }\end{array}$ & ,091 & ,087 & $165^{* *}$ & 1 & $203^{* *}$ & $225^{* *}$ \\
\hline & Sig. (2-tailed) &, 069 & , 084 & ,001 & &, 000 & ,000 \\
\hline & $\mathrm{N}$ & 398 & 398 & 398 & 398 & 398 & 398 \\
\hline \multirow[t]{3}{*}{$\begin{array}{l}\text { Government } \\
\text { policy }\end{array}$} & $\begin{array}{l}\text { Pearson } \\
\text { Correlation }\end{array}$ & $477^{* *}$ & $495^{* *}$ & $682^{* *}$ & $203^{* *}$ & 1 &, $515^{* *}$ \\
\hline & Sig. (2-tailed) &, 000 &, 000 &, 000 &, 000 & &, 000 \\
\hline & $\mathrm{N}$ & 398 & 398 & 398 & 398 & 398 & 398 \\
\hline \multirow[t]{3}{*}{ Prosperity } & $\begin{array}{l}\text { Pearson } \\
\text { Correlation }\end{array}$ & ,408 &, $405^{* *}$ & $478^{* *}$ & ,225* &, $515^{* *}$ & 1 \\
\hline & Sig. (2-tailed) & ,000 & ,000 &, 000 &, 000 &, 000 & \\
\hline & $\mathrm{N}$ & 398 & 398 & 398 & 398 & 398 & 398 \\
\hline
\end{tabular}

Based on the data tabulation, it shows that the correlation value between ethic variable and demography characteristic is 0.551 . Whereas the consumption ethic variable and religious is 0.446 . The correlation between consumption ethic variable and income is 0.091 . The correlation between consumption ethic variable and prosperity is 0.408 . The correlation between demography characteristic variable and the government policy is 0.495 . The correlation between the demography characteristic variable and the prosperity is 0.405 . The correlation between religious variable and income is 0.165 . the correlation between religious and the government policy is 0.682 . The correlation between religious and the prosperity is 0.478 . The correlation between income variable and the government policy is 0.203 . The correlation between income variable and the prosperity is 0.225 . The correlation between the government policy and the prosperity is 0.515 .

\subsection{Analysis of Hypothesis Test}

\section{Simultaneous Test Hypothesis ( $F$ test)}

The test $F$ is used to know the effect of independent variable in the together model with the independent variable, it is the effect of consumption ethic, demography characteristic, religious and income to the government policy. The test result $F$ can be can be shown in Table 2 as stated below:

Table 2. The test result hypothesis together

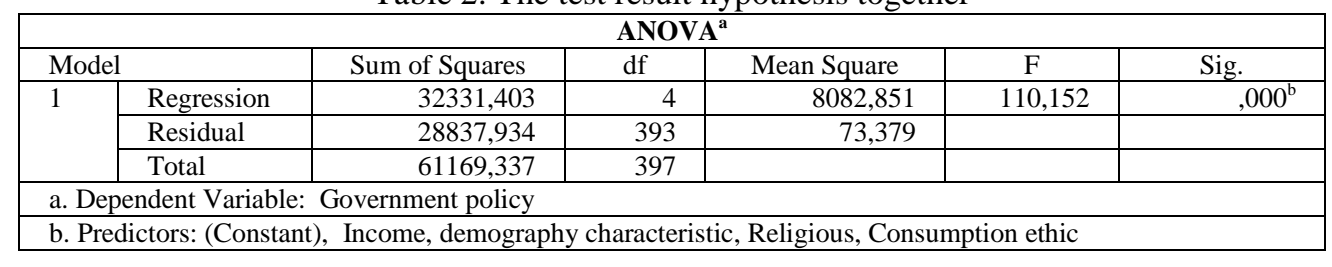

The test is conducted in two ways, the first is that the value of F-calculated and F-table are compared, the second is to compare the value of significant standard (sig) in the calculation result and significant standard $0.05(5 \%)$. Based on the calculation that the value of F-calculate is $110.152>$ F-table 2.37 , thus $\mathrm{H} 0$ is rejected and $\mathrm{Ha}$ is accepted. It means that there is the effect of consumption ethic, demography characteristic, religious and income on the government policy. Whereas the calculation result of significant value in this research is 
$0.00<0.05$. It means that there is the effect of consumption ethic, demography characteristic, religious and income on the government policy.

\section{Partial Test Hypothesis}

The statistic test $t$ is used to know the effect of independent variable (consumption ethic, demography characteristic, religious and income) on the dependent variable (government policy). It is individual or partial. The test result $t$ is shown in Table 3 as stated below:

Table 3. Partial result test (test $t$ )

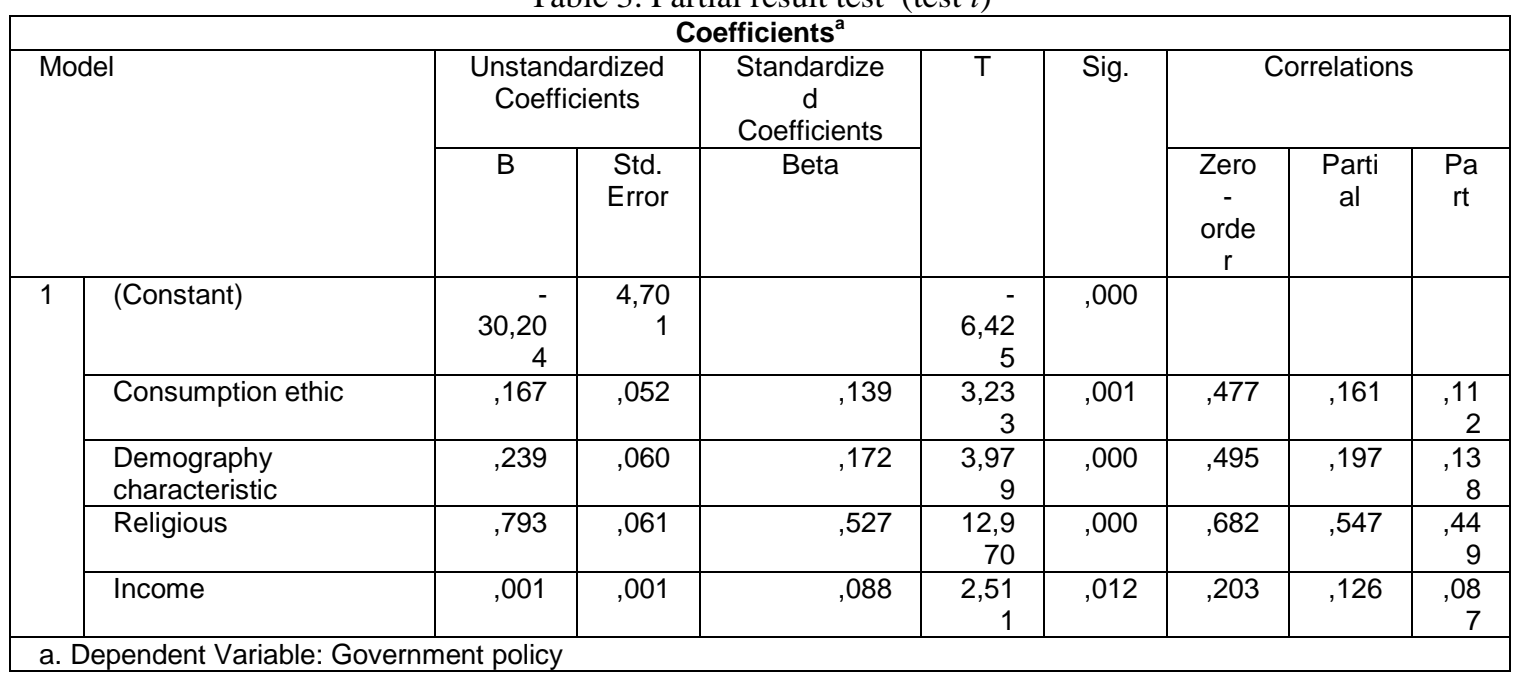

3. Test Result of Simultaneous Determination Coefficient a $R$ square as stated below:

Table 4. Test result of Simultaneous Determination Coefficient $\quad\left(\mathrm{R}^{2)}\right)$

\begin{tabular}{|l|r|r|r|r|}
\hline \multicolumn{3}{|l|}{ Model Summary } \\
\hline Model & $\mathrm{R}$ & R Square & Adjusted R Square & Std. Error of the Estimate \\
\hline 1 &, $727^{\mathrm{a}}$ &, 529 &, 524 & 8,566 \\
\hline \multicolumn{2}{|l|}{ a. Predictors: (Constant), income, demography characteristic, Religious, Consumption ethic } \\
\hline
\end{tabular}

The value standard $\mathrm{R}$ square $\left(\mathrm{r}^{2}\right)$ is 0.529 . The value is used to know the effect of consumption ethic, demography characteristic, religious and income on the government policy by calculating the determination coefficient (KD) by using a formulation as stated below:

$$
\begin{aligned}
\mathrm{KD} & =\mathrm{r}^{2} \times 100 \% \\
\mathrm{KD} & =0,529 \times 100 \% \\
\mathrm{KD} & =52,9 \%
\end{aligned}
$$

The value indicate that the effect of consumption ethic, demography characteristic, religious and income on the government policy in the simultaneous is $52.9 \%$. Whereas the balance is $47.1 \%$ depends on the other factors. It means that the variable of the government policy that it is explained using variable of consumption ethic, demography characteristic, religious and income have avalue of $52.9 \%$, while the effect of $47.1 \%$ is caused by the other variables outside of this model.

\section{CONCLUSION}

Based on the simultaneous shows that the variable of consumption ethic, demography characteristic, religious and income affect to the government policy. The calculation result shows that the value of Fcalculated is $110.152>$ F-table of 2.37 and value of significant in this research is $0.00<0.05$. The effect standard of consumption ethic, demography characteristic, religious and income affect to the government policy in simultaneous is $52.9 \%$. Whereas the balance is $47.1 \%$ is affected by the other factor. The variable of government policy that it can be explained using the variable of consumption ethic, demography characteristic, religious and income is $52.9 \%$, while the effect of $47.1 \%$ is caused by the other variable that outside of this model. 


\section{REFERENCES}

[1] Board of Center Statistic in Regency of South Tapanuli, South Tapanuli in value 2015, South Tapanuli: Board of Center Statistic in Regency of South Tapanuli, 2015.

[2] Rahardjo, M. Darmawan. Islamic Econimic Architecture Toward Social Prosperity. Bandung: Mizan, 2015

[3] P3EI UII Yogyakarta, Islamic Economic, Jakarta: PT. Raja Grafindo Persada, 2008.

[4] Chapra, M Umar What is Islamic Economics?, Islamic Development Bank (IDB), Islamic Research And Training Institute (IRTI), 2001.

[5] Sugiyono, Business Research Method, Ed. 16, Bandung, Alfabeta, 2012.

[6] Arikunto, Suharsini, research Procedure: A Practical Approack, Jakarta: Rineka Cipta, 2010. 